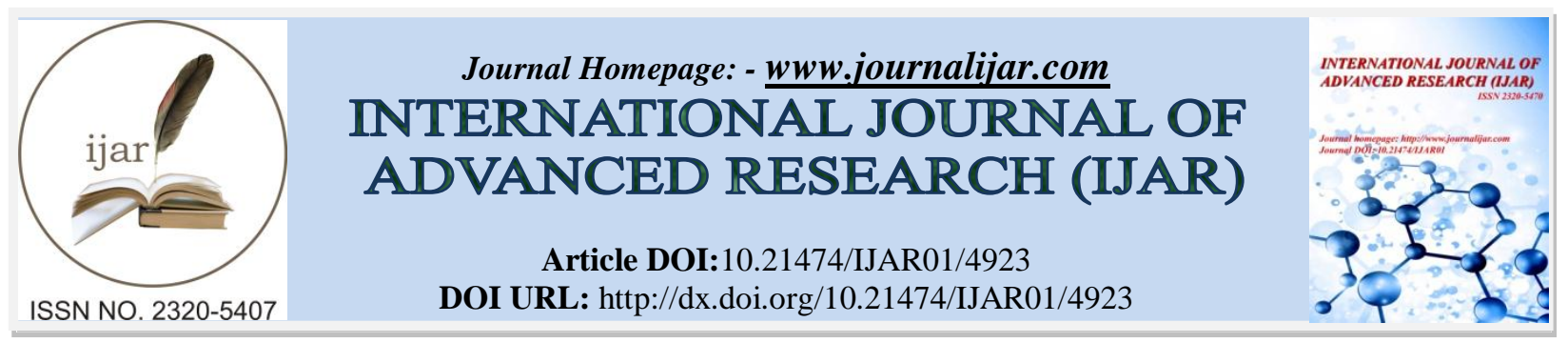

RESEARCH ARTICLE

\title{
PROVENANCE VARIATION IN SEED, POD, GERMINATION AND SEEDLING CHARACTERISTICS IN NATURAL POPULATIONS OF DALBERGIA SISSOO IN CHHATTISGARH INDIA.
}

Sunil Kumar Tiwari andS SDhuria.

Department of Forestry, Wildlife and Environmental Sciences School of Natural Resources, Guru GhasidasVishwavidhyalaya, Bilaspur, Chhattisgarh, India, 495009.

\section{Manuscript Info}

(1........................

Manuscript History

Received: 22 May 2017

Final Accepted: 24 June 2017

Published: July 2017

Key words:-

Dalbergiasissoo, provenance,

germination, vigor.

\section{Abstract}

Variability studies in different seed sources of Dalbergiasissoowith respect to seed, pod, germination and seedling traits were under taken at Deparmentalnursery,glasshouse.Five provenances namely Bilaspur, Bastar, Korba, Raigarh and Sarguja of Chhattisgarh,India were used in the study. The study revealed that highly significant differences among provenances in all studied parameters except pod thickness. Highest variation among provenances in seed traits was observed in seed weight and seed length while seed thickness had the lowest variation. Overall mean germination among provenances was $70.2 \%$ varying from 32.7 to $93.3 \%$. Most of the traits showed significant correlation with geographical factors viz. longitude, latitude and altitude. The observed variation will enable selection of provenances with desired traits for tree improvement and recommendation of specific provenances for different sites.

Copy Right, IJAR, 2017,. All rights reserved.

\section{Introduction:-}

A major component in forest management is the selection of seed sources for reforestation to ensure a successful crop (Shu et al., 2012). This component could be assisted by seed zone and seed transfer rules, by determining the size of seed zones there by reducing the risk of planting poorly adapted trees (Hamann et al., 2000) and ensuring the use of well-adapted planting stock (Ibrahim et al., 1997). For a successful promotion of large scale plantations, there is a need for carefully planned and well directed seed source research. The most successful tree improvement programme is that where proper seed sources were used. The loss from using the wrong sources can be great and even disastrous (Zobel and Talbert, 1984).

Provenance variation, with respect to morphological, anatomical, physiological and biochemical traits, has been studied by many authors (Hattermer 1991, Thapliyal\&Dhiman 1997, Kundu\&Tigerstedt 1999). Because of its wide distributional range with varying geographic, climatic and edaphic conditions and its long evolutionary history, a large variation within and among species is likely to occur, which may be reflected in the genetic constitution of its diverse populations. Seed source variation with respect to cone, seed and seedling characteristics is well documented for a number of tree species (Yeatman 1966, Roy et al. 2004, Mukherjee 2005). More recently, the attention has been focussed on morphological and physiological characteristics of seedling to assess the field performance potential of nursery stock (Omi 1991).

The present investigation was therefore, undertaken to assess the magnitude of variation in seed and seedling characteristics and the extent of genetic control in these parameters. Correlation among various parameters and 
geographical variation existing in different populations of Dalbergiasissoo sampled from wide range of distribution in Chhattisgarh were studied. Such investigation will help in the early evaluation of criteria for selection of some prominent traits both in laboratory and nursery and could be used as an index for the evaluation of provenances or progeny trials in Dalbergiasissoo for further improvement.

\section{Material and Methodology:-}

The fully mature seeds were collected from the five provenances of Chhattisgarh, India (Geographical Location: Table:1). The air dried seeds with a moisture content of $7.660 \pm 0.84 \%$,

To determine the variability in seed and pod morphological characters, seed length, seed width, seed thickness, seed weight, pod length, pod width, pod thickness, pod weight were measured for each provenance. A total of 150 seeds per provenance were randomly selected (3 replicates of 50 seeds) and organized in a completely randomized design (CRD) for measuring each morphological character (that is, $50 \times 3 \times 5=750$ experimental units). Measurement was made on individual seed using a vernier caliper for seed \& pod length, seed \& pod width and seed\& pod thickness and an electronic weighing balance for seed and pod weight.

Table1:-Geographical description of seed collection sites of Dalbergiasissoo from five provenances of Chhattisgarh.

\begin{tabular}{|l|l|l|l|}
\hline Provenance & Latitude $(\mathbf{N})$ & Longitude $(\mathbf{E})$ & Altitude $(\mathbf{m})$ \\
\hline Bilaspur & $21^{0} 47^{\circ}$ & $81^{0} 14$ & 265.00 \\
\hline Bastar & $19^{\circ} .10$ & $81^{\circ} .95$ & 552.00 \\
\hline Korba & $22^{0} .35$ & $82^{\circ} .68$ & 304.80 \\
\hline Raigarh & $21^{0} .90^{\circ}$ & $83^{\circ} .40$ & 215.00 \\
\hline Sarguja & $22^{\circ} .50$ & $82^{\circ} .50$ & 611.00 \\
\hline
\end{tabular}

Hundred seeds were used for each provenance. Each treatment was replicated five times with 20 seeds in each replicate and the whole experiment was arranged in a Randomized Block Design. The experiment was carried out in polypots to study the germination and early seedling growth. A soil mixture was prepared for the experiment. Sand, clay and FYM (Farm Yard Manure) in a ratio 2:1:1. The polypots were filled with this soil and the seeds were sown for germination in the polypots in the same orientation. Then the seeds were sown in polypots in the Departmental Nursery. Fertilizers were not used and the seedlings were irrigated daily.

Germination described by the presence of a radicle at least $2 \mathrm{~mm}$ long (Mackay et al., 1995). The germinated seeds were counted daily from the starting of the experiment up to the end of the experiment (30 days after seed sowing) and then the germination percentage was calculated (ISTA 1999).Germination energy index (GEI) was calculated from daily germination record. For germination energy index an appropriate record of newly germinated seeds was made and GEI calculated by equation (ISTA.1976). For germination value (GV) germination data were considered upto the day when germination became constant for three consecutive days (peak value). The same day was used as a reference point for computing the germination value and was calculated by following equation (Czabator 1962).The germination speed (S) was determined by using the following equation (Chiapuso et al., 1997).Vigor indexwas calculated by using the following equation:-

$$
\mathrm{V}=\% \mathrm{G} \times(\mathrm{ASL}+\mathrm{ARL})
$$

Where $\mathrm{V}=$ Vigor index, $\% \mathrm{G}=$ germination percentage, ASL = Average shoot length, and ARL = Average root length.

Shoot length, leaf \& leaflet dimensions, rooting pattern were measured on the final day of germination studies.

Data collected on seed morphology, germination and early seedling growth parameters were subjected to Analysis of Variance (ANOVA). This was done to determine the variation among provenances at a 0.05 significant level. The Duncan multiple range test was used to compare means among provenances.

\section{Result:-}

The geographical range of seed sources extended from, latitude varied between $19^{\circ} 10^{\prime}$ to $22^{\circ} 5^{\prime} \mathrm{N}$ latitude , longitude varied from $81^{\circ} 14^{\prime}$ to $83^{\circ} 4^{\prime}$ and 265 to $611 \mathrm{~m}$ altitude (Table 1$)$, significant variation $(\mathrm{p}<0.05)$ were observed in pod length, width, number of seeds per pod among seed sources. The highest pod length and width were recorded in Sarguja and Bastar $(7.68 \mathrm{~cm} \& 2.27 \mathrm{~cm})$ followed closely by Bastar and Sarguja provenance (Table 2) whereas, the 
least values for these traits $(4.84 \mathrm{~cm} \& 1.45 \mathrm{~cm})$ were recorded in Korba provenance. Highest pod weight was recorded for Bastar (2.82gm) provenance and, it was followed by Bilaspur(1.94gm)and Sarguja $(1.87 \mathrm{gm})$, the average pod thickness does not show any significant variation across the different provenances. Wide and significant variations were observed among provenances for total number of seeds/pod, number of healthy seeds/pod and damaged seeds/pod. Total number of seeds/pod varied from 3 (Korba) to5 (Bastar and Sarguja) provenance number of healthy seeds/pod was recorded in Sarguja provenance followed by Bastar while the minimum value was observed in Korba provenance.

Table 2:- Pod characteristics in different provenances of Dalbergiasissoo from Chhattisgarh.

\begin{tabular}{|c|c|c|c|c|c|}
\hline Provenances & $\begin{array}{l}\text { Pod weight } \\
(\mathbf{g m})\end{array}$ & $\begin{array}{l}\text { Pod Length } \\
(\mathbf{c m})\end{array}$ & $\begin{array}{l}\text { Pod Width } \\
(\mathbf{c m})\end{array}$ & $\begin{array}{l}\text { Pod Thickness } \\
(\mathbf{c m})\end{array}$ & $\begin{array}{l}\text { Avg. Seeds } \\
\text { per Pod }\end{array}$ \\
\hline Bilaspur & $1.94 \pm 0.19$ & $5.68 \pm 1.32$ & $1.84 \pm 0.12$ & $0.198 \pm 0.10$ & $04 \pm 1.00$ \\
Bastar & $2.82 \pm 0.12$ & $7.22 \pm 1.24$ & $2.27 \pm 0.27$ & $0.180 \pm 0.11$ & $05 \pm 1.12$ \\
Korba & $0.94 \pm 0.10$ & $4.84 \pm 1.01$ & $1.45 \pm 0.18$ & $0.144 \pm 0.09$ & $03 \pm 1.00$ \\
Raigarh & $1.56 \pm 0.21$ & $6.14 \pm 1.24$ & $1.72 \pm 0.21$ & $0.164 \pm 0.12$ & $04 \pm 1.18$ \\
Sarguja & $1.87 \pm 0.17$ & $7.68 \pm 0.94$ & $2.12 \pm 0.15$ & $0.158 \pm 0.07$ & $05 \pm 1.14$ \\
\hline Mean & 1.820 & 6.312 & 1.826 & 0.168 & 4.200 \\
SD & 0.681 & 1.150 & 0.376 & 0.020 & 0.836 \\
$\mathbf{R}^{2}$ & 0.998 & 0.998 & 0.997 & 0.285 & 0.845 \\
F Value & 1153.9 & 1410.4 & 779.9 & 0.999 & 13.66 \\
P Value & 0.001 & 0.0001 & 0.001 & 0.452 & 0.000 \\
\hline
\end{tabular}

The highest average Seed length, width, thickness and weight also varied among provenances (Table 3). Seed length varied from $(0.528 \mathrm{~cm})$ Raigarh to $(0.848 \mathrm{~cm})$ Bastar provenance. The seed width ranged $(0.394 \mathrm{~cm})$ Raigarh to $(0.510 \mathrm{~cm})$ Bastar provenance. However differences in seed thickness were very low, maximum seed thickness $(0.222 \mathrm{~cm})$ was recorded in the seeds of Korba provenance, which was closely followed by Bastar $(0.212 \mathrm{~cm})$ provenance. While the minimum value $(0.146 \mathrm{~cm})$ for seed thickness was recorded in Raigarh provenance. Highest seed weight $(0.072 \mathrm{gm})$ was recorded Bastar provenance which was followed by Sarguja $(0.070 \mathrm{gm})$ and the least value was recorded in Korba $(0.057 \mathrm{gm})$ provenance, closely followed by Bilaspur $(0.060 \mathrm{~g})$ provenance (Table 3$)$. The color of the seeds also showed a wide variability across different provenances.

Table3:- Seed characteristics in different provenances of Dalbergiasissoo from Chhattisgarh.

\begin{tabular}{|l|c|c|c|c|c|}
\hline Provenances & $\begin{array}{c}\text { Seeds weight } \\
(\mathbf{g m})\end{array}$ & $\begin{array}{c}\text { Seed Length } \\
(\mathbf{c m})\end{array}$ & Seed Width $(\mathbf{c m})$ & $\begin{array}{c}\text { Seed Thickness } \\
(\mathbf{c m})\end{array}$ & $\begin{array}{c}\text { Viability } \\
\text { test }\end{array}$ \\
\hline Bilaspur & $0.060 \pm 0.001$ & $0.662 \pm 0.022$ & $0.442 \pm 0.033$ & $0.200 \pm 0.020$ & $97.5 \pm 2.25$ \\
$\quad$ Bastar & $0.072 \pm 0.001$ & $0.848 \pm 0.019$ & $0.510 \pm 0.045$ & $0.212 \pm 0.011$ & $95.0 \pm 2.32$ \\
Korba & $0.057 \pm 0.001$ & $0.557 \pm 0.024$ & $0.401 \pm 0.017$ & $0.222 \pm 0.018$ & $85.0 \pm 1.94$ \\
Raigarh & $0.065 \pm 0.002$ & $0.528 \pm 0.029$ & $0.394 \pm 0.025$ & $0.146 \pm 0.010$ & $90.6 \pm 3.65$ \\
$\quad$ Sarguja & $0.070 \pm 0.001$ & $0.607 \pm 0.029$ & $0.425 \pm 0.029$ & $0.162 \pm 0.021$ & $100.0 \pm 2.28$ \\
\hline MEAN & 0.0648 & 0.6404 & 0.4344 & 0.1884 & 93.62 \\
SD & 0.0057 & 0.1133 & 0.0414 & 0.0293 & 5.312 \\
R $^{2}$ & 0.852 & 0.972 & 0.949 & 0.976 & 0.976 \\
F Value & 14.39 & 87.41 & 46.180 & 100.03 & 109.05 \\
P Value & 0.001 & 0.021 & 0.0001 & 0.0002 & 0.0017 \\
\hline
\end{tabular}

The Significant variation in germination traits was observed across the different provenances of Dalbergiasissoo. Maximum germination percentage was recorded by Bastar (67\%) provenance, while minimum by Korba (48 \%) provenance, However the germination percentage of Sarguja $(65 \%)$ and Raigarh $(60 \%)$ were also better than Korba and Bilaspur(54\%). The germination value of Seeds of Dalbergiasissoo varied from 42.60 (Bastar provenance) to 21.2 (Korba provenance), The seeds of Bastar and Sarguja provenance recorded highest germination speed (12.5 each) and least germination speed was obtained by the seeds of Korba (6.5) provenance. The Highest survival percent (100\%) was recorded by the seedling obtained from the seeds of Bilaspur and Sarguja(100\% each) Provenance, however minimum survival percent $(85 \%)$ was recorded by Korba provenance. 


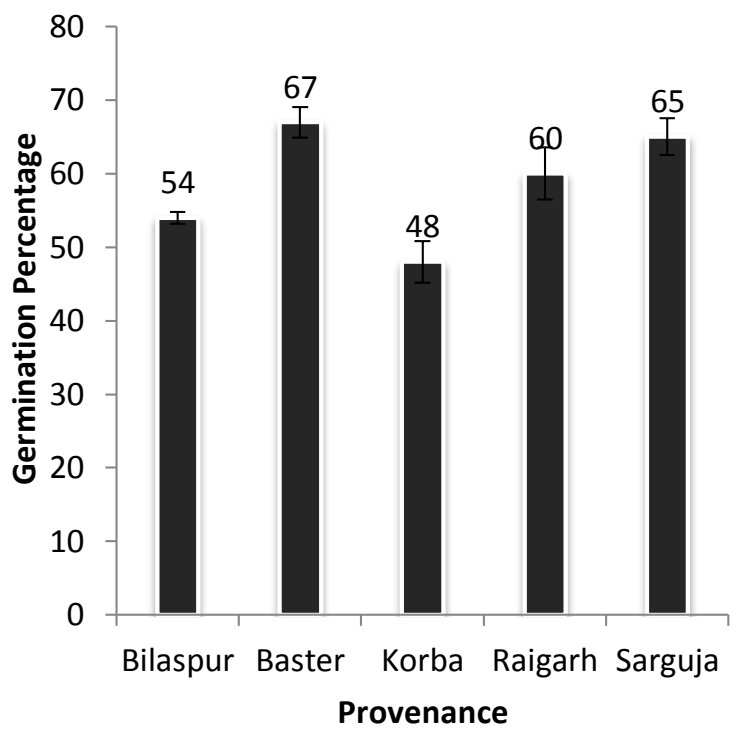

Fig 1:-Germination percentage of five provenances of Dalbergiasissoo. The data shown are mean $\pm \mathrm{SE}$ of four replicates.

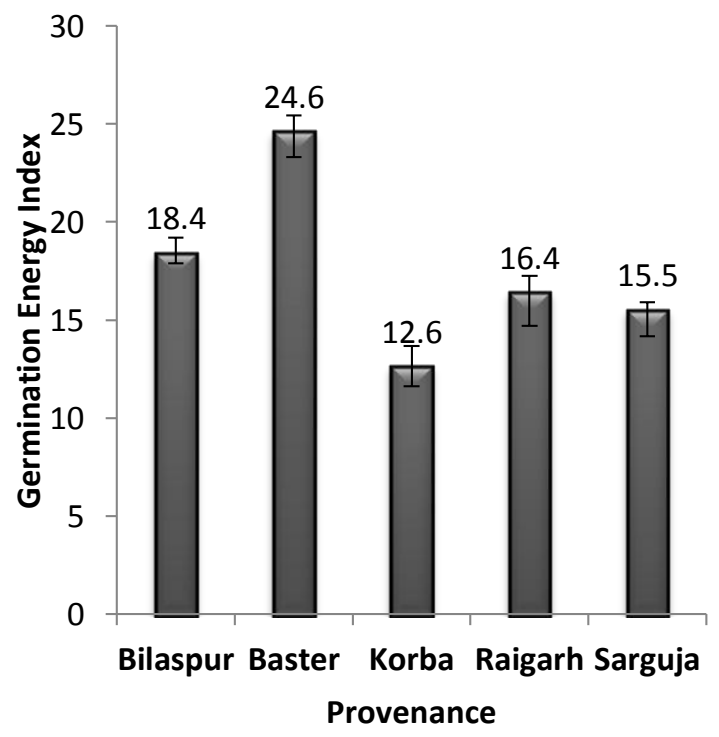

Fig 3:-Germination Energy Index of five provenances of Dalbergiasissoo. The data shown are mean \pm SE of four replicates.

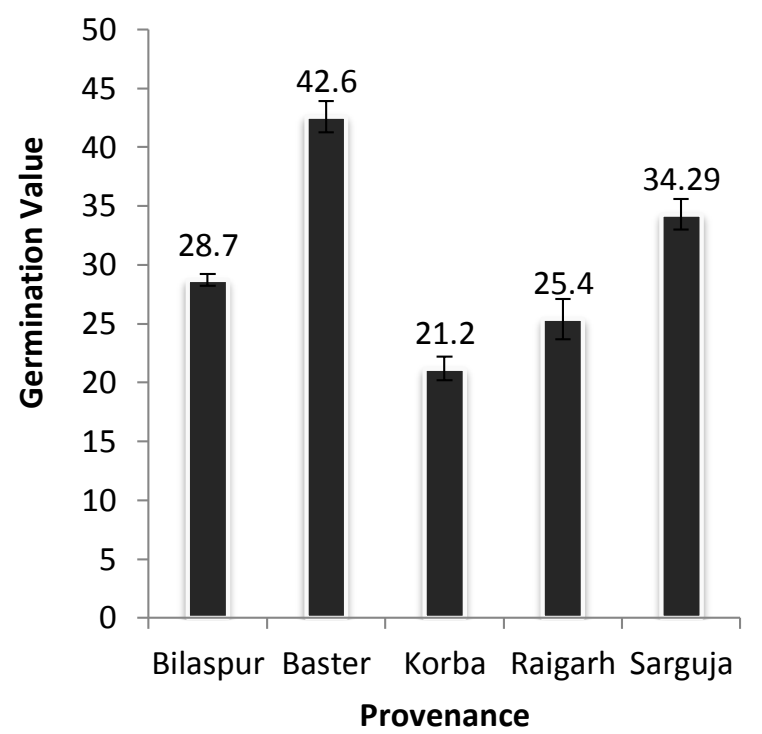

Fig 2:-Germination Value of five provenances of Dalbergiasissoo. The data shown are mean $\pm \mathrm{SE}$ of four replicates.

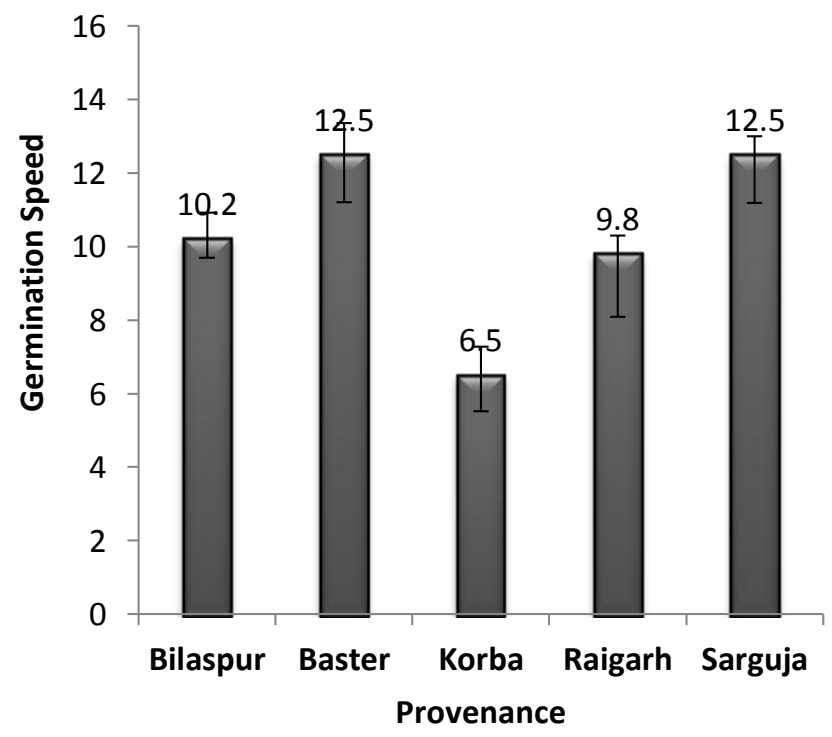

Fig 4:-Germination Speed of five provenances of Dalbergiasissoo. The data shown are mean $\pm \mathrm{SE}$ of four replicates. 


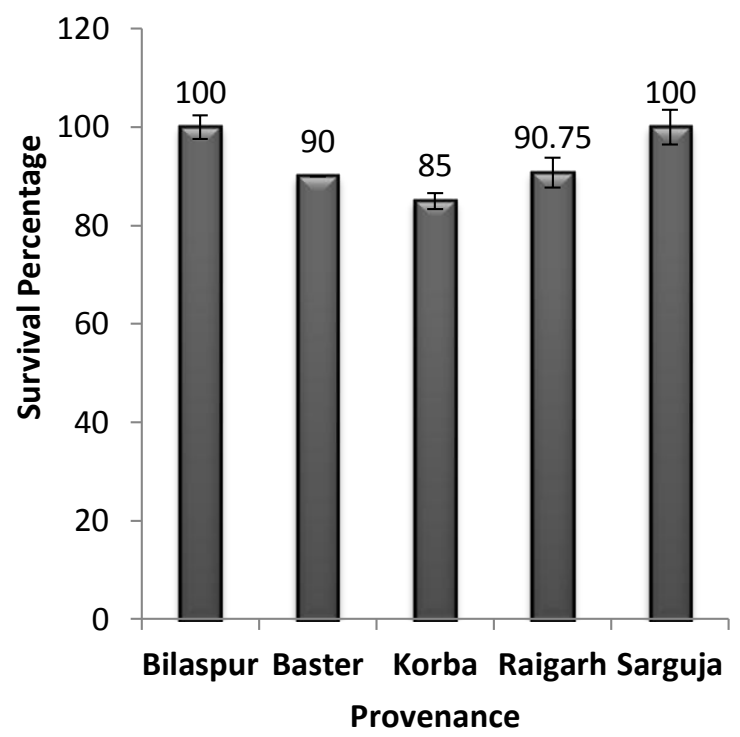

Fig 5:-Survival percentage of five provenances of Dalbergiasissoo. The data shown are mean \pm SE of four replicates.

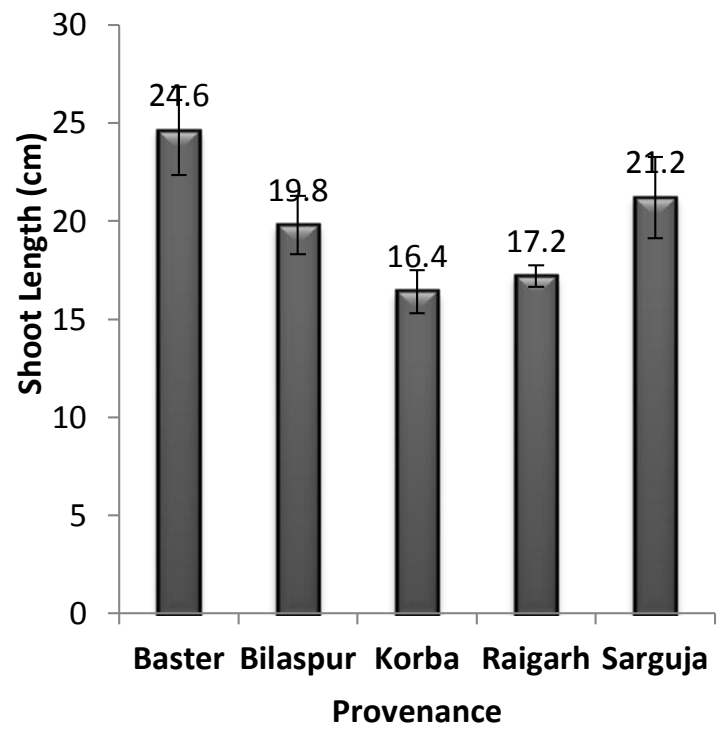

Fig 15:-Average shoot length $(\mathrm{cm})$ per seedling of five provenances of Dalbergiasissoo. The data shown are mean \pm SE of four replicates.

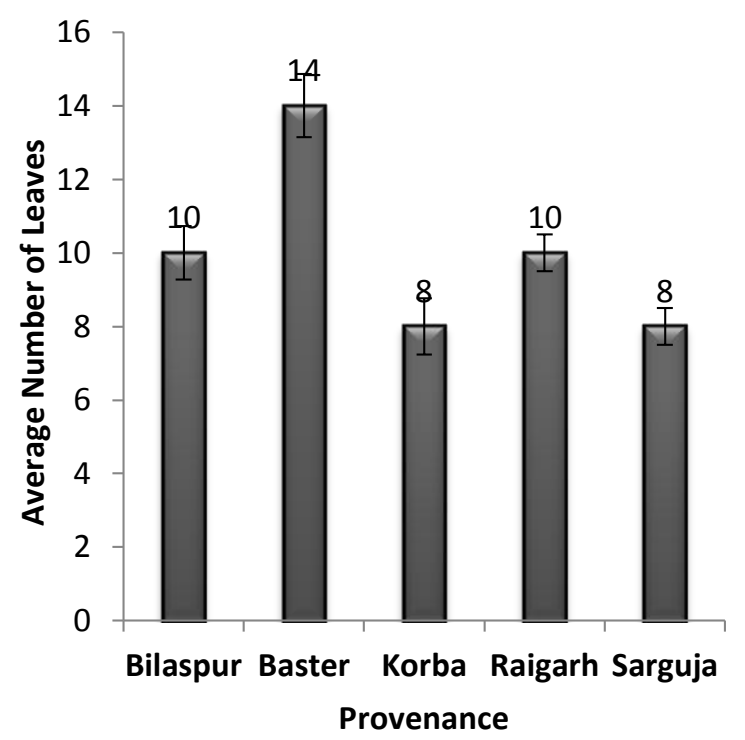

Fig 6:-Average number of leaves per seedling of five provenances of Dalbergiasissoo. The data shown are mean \pm $\mathrm{SE}$ of four replicates.

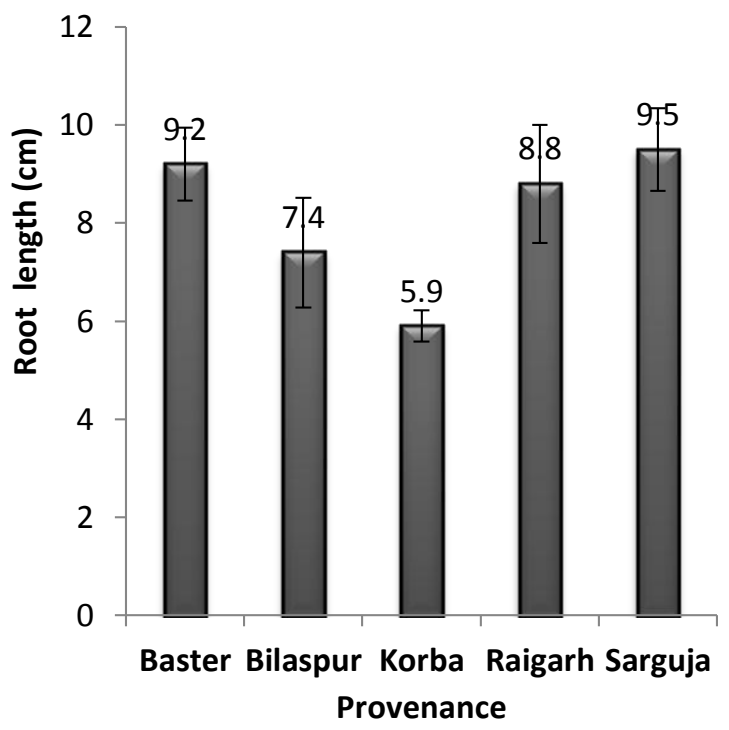

Fig 16:-Average root length $(\mathrm{cm})$ per seedling of five provenances of Dalbergiasissoo. The data shown are mean \pm SE of four replicates.

The shoot and root length of Dalbergiasissoo were significantly different across the different provenances of Chhattisgarh, India. The length of the shoot was recorded highest by the Bastar provenance. In contrast, the Korbaprovenance record a minimum length of shoot. The length of root was observed highest in Sarguja provenance and minimum root length was recorded in the seedlings of Korba provenance.

\section{Discussion:-}

A critical decision in forest resource management is the choice of seed sources for reforestation to ensure a successful crop. Seed zones and seed transfer are essential tools in assisting this decision in order to avoid planting poorly adapted trees (Hamann et al., 2000). Provenance studies can act as a prerequisite for genetic improvement of any 
tree species. Selection of the elite provenance of desired forest tree species for a given site is necessary for achieving maximum gain in plantation forestry.

This present study of provenance variation in Dalbergiasissoo recorded a significant variation seed/pod size, shape and weight, in germination percentages and in growth characteristics (seedling height, number of leaves/plant, number of lateral root, leaf area/plant, root length). Variation among seed provenances with respect to seed/pod traits (length, width, thickness and weight) have earlier been reported in many forest tree species i.e., Dalbergiamelanoxylon (Amri et al., 2008), Acacia karroo (Abdelkhair et al., 2003), Pinusroxbrughii (Ghildiyal et al., 2009) and Celtisaustralis (Singh et al., 2006). Elmagboul et al. (2014) hypothesised that variation in seed weight, length, width and thickness between or within plant species are due to evolutionary responses of plants to maximize the potential fitness by producing a larger number of seeds and increase the chance of establishment of resulting seedlings through greater allocation of maternal resources to individual seeds. Variation among the provenances may also be due to genetic differences caused by the adaptation to diverse environmental conditions (Ginwal et al., 2005).

The germination behavior in Dalbergiasissoo was found to be significantly different across different provenances.Variation in germination behavior that occurs among different populations within the same species has been widely reported ( Marova, 2010). The inter-population variability in germinability can be due to environmental differences or to genetic variation. Indeed, inter-population seed dormancy variability can serve as an adaptation strategy in unpredictable environments (Cruz et al., 2003; Giménez-Benavides, 2005). In the present study it was observed that the seeds/pods from Raigarh and Sarguja provenances exhibited similarity in seed/pod size.

The study confirmed the existence of considerable variation among provenances with respect to seed/pod morphological characters, germination and seedling growth of Dalbergiasissoo. The best two provenances recommended from this study based on germination, growth and vigor for integration within this region are Bilaspur and Bastar, because they have high germination capacity and also exhibited highest germination speed. The overall vigor of the seedlings of these provenances was higher than other provenances. This will also ensure provision of planting materials for farmers. Finally the recommendations of present study enhance the selection of the most suitable provenances of Dalbergiasissoo for breeding and conservation in the area of study.

\section{References:-}

1. Amri E, Lyaruu HVM, Nyomora AMS, Kanyeka ZL (2008). Effect of timing of seed collection and provenance on seed viability and germination of Dalbergiamelanoxylon. Bot. Res. J. 1: 82-88.

2. Abdelkheir RM, Ibrahim AM, Khalill AA (2003). Provenance variation in seed and germination characteristics of Acacia karroo. Sudan Silva 9(2): 14-26.

3. Cruz A, Perez B, Velasco A, Moreno JM (2003). Variability in seed germination at the inter population and intra individual levels of shrub Erica australis in response to fire-related cues. Plant Ecol 169:93-103.

4. Chiapuso G, Sanchez AM, Reigosa MJ, Gonzalez L, Pellissier F (1997) Do germination indices

5. adequately reflect allelochemical effects on the germination process. Journal of ChemicalEcology 23: 24452453.

6. Czabator FJ (1962) Germination value: an index combining speed and completeness of Pine seed germination. Forest Science 8: 386-396.

7. Elmagboul H, Mahgoup S, Eldoma A (2014). Variation in seed morphometric characteristics and germination of Acacia tortilis subspecies raddiana and subspecies spirocarpa among three provenances in Sudan. Global J. Bio-Sci. Biotechnol. 3(2): 191-196.

8. Ghildiyal SK, Sharma CM, Gairola S (2009). Additive genetic variation in seedling growth and biomass of fourteen Pinusroxburghii provenances from Garhwal Himalaya. Indian J. Sci. Technol. 2(1): 37-45.

9. Ginwal HS, Phartyal SS, Rawat PS, Srivastava RL (2005). Seed source variation in morphology, germination and seedling growth of Jatrophacurcaslinn in central India. Silvae Genet. 54(2): 76-79.

10. Gimenez-Benavides L, Escudero A, Pérez-García F (2005). Seed germination of high mountain Mediterranean species: altitudinal, interpopulation and interannual variability. Ecol Res 20:433-444.

11. Hamann A, Koshy MP, Namkoong G, Ying CC (2000). Genotype $\times$ environment interactions in Alnusrubra: developing seed zones and seed-transfer guidelines with spatial statistics and GIS. Forest EcolManag 136:107119.

12. Hattermer H.H., 1991. Genetic analysis and Population genetics. In Fineschi et al. (eds) Biochemical markers in the population genetics of forest trees. SPB Academics Publishing, The Hague, pp 5-22. 
13. Ibrahim AM, Fagg CW, Harris SA (1997). Seed and seedling variation amongst provenances in Faidherbiaalbida. For. Ecol. Manag. 97(2): 197-205.

14. ISTA., 1976. International Rules for Seed Testing, International Seed Testing Association. Seed Science \& Technology, 21.

15. International Seed Testing Association (ISTA) (1999) International rules for seed testing. Seed Science and Technology 27: 333.

16. Kundu S.K., Tigerstedt P.M.A., 1999. Variation in net photosynthesis, stomatal characteristics, leaf area and whole plant phytomass production among ten provenances of neem (Azadirachtaindica). Tree Physiology. 19 (1): 47-52.

17. MackayWA, DavisTD and D sankhla(1995),Influence of scarification and temperature treatments on seed germination of Lupines havardii.Seed Science and Technology 23:815-821.

18. Mukherjee S., 2005. Studies on provenance variation in cone, seed and seedling characteristics of PinusroxburghiiSarg. Ph. d. Thesis, Forest Research Institute, Deemed University Dehra Dun.

19. Marova IM, Ivanitskii VV, Veprintseva OD (2010). Individual ,population and geographic differentiation in advertising song of the Blyth's reed warbler, Acrocephalusdumetorum (Sylvidae). Biol Bull 37:846-860.

20. Omi S.K., 1991. The target seedling and how to produce it. In: Texas Forest service. Proceedings from the nursery management workshop, Sept. 10-12, Texas, pp. 88-118.

21. Roy M.S., Thapliyal R.C., Phartyal S.S., 2004. Seed source variation in cone, seed and seedling characteristics across the natural distribution of Himalayan low level pine Pinusroxburghiisarg. SilvaeGenetica 53(3): 116-122.

22. Shu X, Yang X, Yang Z (2012) Variation in Seed and Seedling Traits among Fifteen Chinese Provenances of Magnolia officinalis. Not Bot Horti Agrobo,40(2):274-283.

23. Singh B, Bhatt BP, Prasad P (2006). Variation in seed and seedling traits of Celtisaustralis, a multipurpose tree, in Central Himalaya, India. Agrofor. Syst. 67(2):115-122.

24. Thaplial R.C., Dhiman R.C., 1997. Geographic variation in seed and seedling characteristics in PinusroxburghiiSarg. from Himachal Pradesh. Annals of Forests 5(2): 140-145.

25. Yeatman C.W., 1966. Germinant size of Jack Pine in relation to seed size and grographic origin. Proceedings of the Second, General Workshop, Society of American Forester, US.

26. Zobel, B., and J. Talbert. 1984. Applied Forest Tree Improvement. 